\title{
From craftsmen to laborers: A history of carpet making in Republican China
}

Des artisans aux ouvriers: une histoire de la fabrication des tapis dans la Chine républicaine

\section{Yujie Li}

\section{OpenEdition}

\section{Journals}

Electronic version

URL: http://journals.openedition.org/artefact/1923

DOI: $10.4000 /$ artefact. 1923

ISSN: 2606-9245

\section{Publisher:}

Association Artefact. Techniques histoire et sciences humaines, Presses universitaires du Midi

\section{Printed version}

Date of publication: 6 December 2018

Number of pages: $49-67$

ISBN: 978-2-8107-0595-5

ISSN: $2273-0753$

Electronic reference

Yujie Li, «From craftsmen to laborers: A history of carpet making in Republican China », Artefact [Online], 8 | 2018, Online since 21 June 2019, connection on 27 November 2020. URL : http:// journals.openedition.org/artefact/1923 ; DOI : https://doi.org/10.4000/artefact.1923

\section{c) (i) $\Theta$}

Artefact, Techniques, histoire et sciences humaines est mise à disposition selon les termes de la Licence Creative Commons Attribution - Pas d'Utilisation Commerciale - Pas de Modification 4.0 International. 


\section{From craftsmen to laborers: A history of carpet making in Republican China}

\section{Yujie Li}

\section{Abstract}

Beijing and Tianjin hand-woven carpets were once a major export item of Republican China. These carpets were mainly bound for the Western markets, especially the United States. In the late Qing dynasty, Chinese carpets found their way into the collections of wealthy connoisseurs and then, increasingly throughout the 1920s, into the homes of America's rising middle class. This paper shows that by pursuing a strategy of export maximization, the Republican Chinese carpet industry submitted itself to technical standards set by the American market, as well as to the shifting tastes of American homemakers. This resulted in the valorization of knowledge about foreign market and devalorization of traditional Chinese artisanal knowledge. Eventually, entrepreneurs with direct connections to the foreign market came to dominate the carpet production; weavers were reduced to manual laborers.

\section{Keywords}

Republic of China, handicrafts, hierarchy of knowledge, authenticity, textile, global trade

99 Yujie Li, « From craftsmen to laborers: A history of carpet making in Republican China », Artefact, 8, 2018, p. 49-67. 


\section{Des artisans aux ouvriers : une histoire de la fabrication des tapis dans la Chine républicaine}

\section{Résumé}

Les tapis tissés à la main de Pékin et de Tientsin ont été l'une des principales exportations de la Chine républicaine. Ces tapis étaient principalement destinés aux marchés occidentaux, particulièrement au marché nord-américain. À la fin de la dynastie Qing, les tapis chinois se retrouvèrent dans les collections de riches connaisseurs puis, de plus en plus dans les années 1920, dans les maisons de la classe moyenne montante américaine. Le présent article montre qu'en suivant une stratégie de maximisation des exportations, l'industrie des tapis en Chine républicaine s'est soumise aux standards techniques du marché américain ainsi qu'aux goûts changeants des ménages américains. Cela a engendré une valorisation de la connaissance du marché étranger et une dévalorisation de la connaissance artisanale chinoise traditionnelle. Enfin, les entrepreneurs ayant des liens directs avec le marché étranger dominèrent la production de tapis. Les tisserands devinrent alors de simples ouvriers.

\section{Mots-clés}

République de Chine, artisanat, hiérarchie de connaissance, authenticité, textile, commerce global 


\section{Introduction}

From the mid 1910s to the mid 1930s, carpets were one of China's most important exports. Destined mainly for the United States, at the peak of the trade in the mid 1920s, these carpets made up nearly one percent of all of China's outbound trade with an export value approximating one third of all cotton exports. ${ }^{1}$ This article investigates the history of carpet making in Republican Beijing and Tianjin. ${ }^{2}$ In doing so, it reveals how changes in Western consumption patterns and international trade dynamics rearranged the political economy of Chinese urban handicrafts production. Specifically, the history of Tianjin and Beijing carpet making provides a new perspective on the decline of artisans' status and on the marginalization of traditional aesthetics in early twentieth century China.

This new perspective contributes to a growing scholarship on the global trade of textiles. Recently, art historians of the early modern period have shown that with the intensification of material exchanges between the East and the West, trade textiles began to "reveal a conglomerate of design and technical features from several different lands". ${ }^{3}$ As early as the midsixteenth century, trade with the Portuguese induced Chinese craftsmen to produce textiles incorporating European and Chinese features, both in terms of material and techniques, as well as in iconography and ornamentation. ${ }^{4}$ The European fetishization of "Chinese taste" in the seventeenth and particularly the eighteenth century, epitomized in the term "Chinoiserie", brought numerous aesthetically hybrid crafts, made in China as well as in Europe, into Europeans domestic decoration. Many cultural historians have shown that European aristocrats and middle-class families alike used

1. Carpets exports valued $0.7 \%$ of the entire Chinese exports in 1925 . This number is based on statistics drawn from following materials: Albert FeuERWERKer, The Chinese Economy, 1912-1949, Michigan, University of Michigan Center for Chinese Studies, 1968. Table 21 shows that China's net exports in 1925 is 1,210 million Chinese dollar; and according to Xianting FANG, Tianjin Carpet Industry, Tianjin, Chihli Press, 1929, the total export of carpet in 1925 amounted to 9,103,775 Chinese Dollar.

2. The convention of oriental carpet market was to name the rugs by the city or town from which it was shipped abroad. Thus Chinese carpets exported during this time were generally recognized as "Tientsin Carpet" in its Western markets.

3. Amelia Peck, "Trade Textiles at the Metropolitan Museum, A History," Interwoven Globe, The Worldwide Textile Trade, 1500-1800, New York, The Metropolitan Museum of Art, 2013, p. 2-11. 4. Maria João Pacheco Ferreira, "Chinese Textiles for Portuguese Tastes," Interwoven Globe, The Worldwide Textile Trade, 1500-1800, New York, The Metropolitan Museum of Art, 2013, p. 46-55. 
Chinese-style decoration to display their socioeconomic status and intellectual inclination. ${ }^{5}$

The global trade in crafts changed dramatically after the mid-nineteenth century. Many handicrafts industries in nonWestern countries grew rapidly to meet expanding Western demand. Traders around the globe began to reorganize handicrafts production. The new hierarchy of the world economy valorized knowledge of faroff markets. In the early-modern market, design innovation was mainly the province of producers. But by the 1920s innovation was increasingly the prerogative of buyers, evincing a shift in market power. This transformation of traditional industries has been most thoroughly examined in the colonial context. Tirthankar Roy discusses in detail the scaling up of the Indian carpet production from the late nineteenth century to the 1930s, and shows how certain traditional institutions, such as the apprenticeship system, evolved under the new political economy of carpet making.

There are also prominent differences between the Chinese and Indian cases. First, the majority of the Chinese carpets were exported to the United States. Americans' enthusiasm for oriental luxuries, described by Kristin Hoganson as learned "secondhand" from the Europe, ${ }^{7}$ came late but rose quickly. The shift of luxury consumption pattern in the American market transformed Chinese traditional carpet workshops into sweatshops in the late 1910s. Second, the handicrafts played a different role in Chinese and Indian nationalist discourses. Chinese nationalists had nothing like an Indian Swadeshi or Japanese Mingei movement, ${ }^{8}$ or indeed any glorifi-

5. Stacey Sloboda, Chinoiserie: Commerce and Critical Ornamant in Eighteenth-Century Britain, Manchester, Manchester University Press, 2014. More on the topic of "Chinoiserie": Hugh Honour, The Vision of Cathay, New York: Dutton, 1961; René Étiemble, L' Europe chinoise, vol. 2, Paris, Gallimard, 1988 and David PorTer, The Chinese Taste in Eighteenth-Century England, Cambridge, Cambridge University Press, 2010.

6. Tirthankar Roy, Traditional Industry in the Economy of Colonial India, Cambridge, Cambridge University Press, 1999. More studies on the transformation of traditional industries in different countries can be found in Gareth Austin ed., Labour Intensive Industrialization in Global History, New York, Routledge, 2013.

7. Kristin Hoganson, Consumers' Imperium: The Global Production of American Domesticity, 18651920. Chapel Hill: University of North Carolina Press, 2007, p. 53.

8. On Mingei Movement, see Kim Brandt, Kingdom of Beauty: Mingei and the Politics of Folk Art in Imperial Japan, Durham, Duke University Press, 2007 and Yuko Kinuchi, Japanese Modernization and Mingei Theory: Cultural Nationalism and the Oriental Orientalism, London, Routledge Curzon, 2004 . 
cation of traditional artisanship. Chinese craftsmen were seen by Chinese nationalists and modernizers as backward and unable to lead the "improvement" of the industry. With China's crushing foreign debt resulting from the unequal treaties imposed by the imperial powers, export maximization became a matter of national sovereignty. ${ }^{9}$ As a result complete submission to the designs and standardization demanded by foreign markets came to be considered not only rational, but nationalist and progressive.

The carpet weavers thus experienced a "degradation of work" in Harry Braverman's sense. Braverman locates "deskilling" in the separation of conception and execution, in the reinterpretation of skill as a specific dexterity and speed, and in the closing of worker access to scientific and managerial knowledge. ${ }^{10}$ The carpet workers' deskilling happened not only in terms of defamiliarization with traditional patterns and traditional Chinese decorative purposes, but more importantly in terms of total alienation from the design conception and from the new technical knowledge such as chromel dyeing or chemical wash. A knotter may still be knotting but his chance to know the trade from soup to nuts let alone run his own business one day had vanished by the late 1920s.

\section{Guilds, apprenticeship and the carpet- making techniques before the 1920s}

The existence of small scale carpet production in northern China had been noticed by westerners by the end of the nineteenth century. In 1894, the United States Department of the Treasury published a report on "Wool and Manufactures of Wool." It urged readers to pay more attention to the potential of Chinese woolen carpets made in the provinces of Zhili, Henan and Shanxi, as, "It might have been expected that those carpets would be exported in much larger volume than it actually is" ${ }^{11}$ In fact, as woolen carpets were never popularized among the ethnic Chinese, these housemade carpets were most likely covers for beds or horse saddles. Large

9. Margherita ZanasI, Saving the Nation: Economic Modernity in Republican China, Chicago, University of Chicago Press, 2006.

10. Harry Braverman, Labor and Monopoly Capital, the Degradation of Work in the Twentieth Century, New York, Monthly Review Press, 1974.

11. Worthington C. Ford, Wool and Manufactures of Wool, Washington, Government Printing Office, 1894, p. 637. 
carpets for palaces and temples were reportedly made in Tibet and Ningxia during the eighteenth century. But since the early nineteenth century, carpet workshops opened in Beijing to supply temples and elite families. ${ }^{12}$ By the end of the Qing dynasty (1644-1912), Beijing carpets had gained a measure of international recognition. At the Louisiana Purchase Exposition held in St. Louis in 1904 - the Qing government's only official participation in a World's Fair - a variety of beautiful carpets were brought by the Beijing Industrial Institute and displayed in the China Exhibition in front of millions of Expo visitors ${ }^{13}$. After the fall of the Qing, international commerce and travel grew at a rapid clip. A steady stream of Chinese carpets made its way into the West as travel souvenirs or as exports. Oriental carpet collectors in New York and elsewhere began to prize Chinese rugs and to show off their new acquisitions. ${ }^{14}$ As more Chinese carpets found their way to foreign markets, Tianjin opened up as a second center of carpet production. It was easy for skilled Beijing carpet makers to move to this neighboring port city, where they enjoyed more convenient access to raw material and closer contact with exporters.

As in many other handicrafts trades, carpet weavers had to go through three to four years of apprenticeship before becoming a journeyman. In his 1919 Beijing Survey, Sidney Gamble states that through an apprenticeship in Chinese handicrafts, young boys became "thoroughly acquainted with hard menial work" and were prepared to become masters of the trade "by constant daily contact". ${ }^{15}$ When the industry boomed in 1916, many workers took advantage of good times to open their own workshops. ${ }^{16}$ This indicates that they had acquired skills not only of weaving but also of management and sales. In short, a carpet worker in a pre-1916 workshop had opportunities to acquire skills and connections with suppliers and

12. Madeleine Yue Dong, Republican Beijing, the City and Its History, Berkeley, University of California Press, 2003.

13. Mark Bennit et al, History of the Louisiana Purchase Exposition, St. Louis, 1905. See also Imperial Commission to Louisiana Purchase Exposition, China: Catalogue of the Collection of Chinese Exhibits at the Louisiana Purchase Exposition, St. Louis, 1904.

14. John K. Mumford, "Chinese Rugs," The Mentor, 102, March 1916, p. 12.

15. Sydney Gamble, Peking: A Social Survey. New York, George H. Doran, 1921, p. 190.

16. Fang Xianting calculated that the total export value of Chinese carpets reached 774,876 HKT in 1916, almost quintuple that of the 1915. With some fluctuations, the carpet export in general continued to grow. 
buyers, as well as the reasonable expection that these might enable him to start his own business.

Carpets were made on vertical wooden looms, with the upper and bottom beams supported by two upright poles at two sides. The width between the beams determined the width of the carpet. Once the poles and beams were fixed at the right position, the carpet making would proceed along the following steps:

1. gua jing or shang jing (stringing the warps): This was done by looping a cotton cord over the top and bottom beams. The "warps" were made by one single thread. It was critical that warps be strung with equal tension. Carpets were categorized by the number of warps per foot. For example, a 90-line carpet had 90 warp strings on a foot of weft. The higher the number of strings, the denser the carpet was. Guo jing was usually done by junior apprentices.

2. hua jing (drawing the design onto the warps): After the warps were tightened between the beams, the design was outlined on the warps. In earlier years, this was done by weavers most familiar with design motifs and skilled at drawing. Later, when the carpets were mostly made on order, commensurate draft was introduced. The commensurate draft was fixed between the two layers of warps. Hua jing became simply tracing the lines on the draft, visible under one layer of warps, onto the warps, an easy job usually assigned to apprentices. The transition to commensurate drafting deprived workers of the opportunity to participate in the aesthetic design of carpets.

3. $d a d i$ (weaving the selvage): Weavers used cotton wefts to weave through the warps and make an inch-wide border for the carpet.

4. shuan tou (knotting): Strictly speaking, a carpet was more knotted than woven. The knotter, passed the string of yarn around two upright warp strings, tying them together in a knot, and then cut off the yarn with a quick blow of a short, heavy knife. This left a small, protruding piece of yarn tied to the warp string. The standing yarn was left slightly longer than the height of pile required. The extra length would be cut off in steps 6 and 8 . The number of knotters attending one carpet depends on the size of the carpet. Typically, a 9x12 feet carpet took four knotters to work in tandem. It was common for one of the knotters to be apprentice. However, in the late 1920s, price competition among Beijing workshops engendered the overexploitation of apprentices. Many carpets were purely knotted by unpaid apprentices.

5. guo wei (wefting through): When the knots were tied on each warp across the loom, the weaver ran a weft through, tamping it down tightly against 
the knots. Then a new line of knots was tied. Knotting and wefting were repeated until the rug was complete.

6. jian hua (clipping): Scissors were used to clip the carpet's surface, making it smooth.

7. xia huo (taking off the carpet): the finished carpet was removed from the loom and placed on even ground.

8. ping huo (smoothing the pile): This was the most skill-demanding step in carpet making. A senior worker specializing in smoothing the pile used a special pair of scissors to clip the rug until the ends were even and the surface smooth. Jian hua and ping huo were so important to the Chinese carpets that payment for these jobs were considerably higher than for weaving.

The sequence of an apprentice's learning corresponded to the carpet making processes. After a few months of simple tasks such as preparing yarns, stringing the warps and transcribing the patterns, an apprentice would learn knotting on a practice loom. He would be tutored in each step by his employer, a manager, a senior worker or, in the worst case, a senior apprentice. Usually between the sixth and twelfth month of his apprenticeship, he would be placed on a real loom with more experienced workers. By being "squeezed between the fast hands," he was pressed to enhance the speed and quality of his work. He would gradually move to making carpets with more complicated patterns, though carpets of the most intricate designs were the exclusive preserve of experienced workers. Clipping and smoothing the carpet, the most difficult steps, would only be taught toward the end of the apprenticeship, if at all. The delay in teaching these skills was not only owing to their difficulty, but also a calculated strategy by workshop masters to prevent boys from acquiring so many skills that they would no longer be dependent on the workshop master. ${ }^{17}$

The young men who apprenticed in the workshops prior to the mid-1910s seem to have gained truly valuable skills. An old industry adage "the old master feels threatened by the two-and-half-year apprentice" speaks to the manual skills developed in years of apprenticeship. But more importantly, the system allowed the young workers to acquire a comprehensive understanding of the operation of the industry in addition to handicraft skills, such that it was common for a young journeyman to start his own

17. Jiaquan Liu, Huazhong Chen, and Dejun Zhong, "The Beijing carpet industry and the conditions of the carpet workers in the old China (BCW)", in Historical Materials of Beijing Workers Movement, Beijing, Beijing General Union Federation, 1982, p. 1-134. 
workshop afte some years of practice. Indeed, all founding workshop masters of the Beijing carpet guild, established in 1905 had started off as apprentices.

World War I caused the rate of growth to spike dramatically. After the war broke out and Western markets found themselves cut off from near-eastern suppliers, demand for Chinese carpets surged. Increased demand was a mixed blessing for the guild. It meant greater prosperity for member workshops, whose revenue spiked as carpet exports from Tianjin doubled from 57,109 HK Taels in 1912 to 103,776 HK Taels in 1914, and then spiked to $774,876 \mathrm{HKT}$ in $1916 .{ }^{18}$ But high overseas demand attracted new competitors. During the same period, hundreds of new looms were set up, thousands of young apprentices were recruited, and carpet workshops multiplied to meet the increasing appetite for Chinese carpets.

This surge in demand ultimately shifted pricing power from Beijing producers to foreign traders. Prior to the war, the Beijing carpet guild had taken the lead in setting sales prices. Established in 1905 to cope with growing demand from tourists and exporters, the guild originally represented a small, tightly-knit group of workshops and the most successful master carpet makers ${ }^{19}$. But by 1916, the proliferation of new entrants occasioned by the war made it impossible for the guild to continue its cartel-like control over either employment or pricing. High labor demand and steep wage inflation induced workshops to hire more unpaid apprentices. The lengthy apprenticeship no longer acted as a check on new workers, or even as a path toward upward mobility. Indeed, apprenticeship began to function less as a training program, and more like free labor. In 1919, roughly half of the five thousand carpet workers in Beijing were unpaid apprentices. By 1924, of the 6,834 carpet workers in Beijing fully 5,066 were apprentices. ${ }^{20}$ The use of apprentices became little more than a cover for exploitative labor practices. As late as 1919 Gamble had still acknowledge apprenticeship as a means of acquiring skills. But by the mid-1920s observers saw unvarnished exploitation and abuse of child

18. X. FANG, Tianjin Carpet Industry, op. cit., p. 238.

19. Xinyu Luo, "Beijing ditan ye diaocha baogao (The Research Report on the Beijing Carpet Industry)," Quan Ye Cong Bao, vol.1, 3, 1921, p. 3.

20. See both S. Gamble, Peking, op. cit. and C.C. Chu and Thomas C. Blaisdell, Peking Rugs and Peking Boys: A Study of the Rug Industry in Peking, Beijing, Chinese Social and Political Science Association, 1924. 
labor. Hence, Chu and Blaisdell lamented that "it is hard to see how the apprentice system, as it now operates, can be dignified by the name of 'apprenticeship.' ... Formerly the apprentice not only learned to make rugs, but also learned how to run the business ... But now he is never his own master". ${ }^{21}$ The industry's spurt of development had rendered both the guild and the apprenticeship system powerless in protecting the trade and the craftsmen. An apprentice had become a manual laborer and was no longer trained to be an artisan who embodied a set of skills that enable him to plan, produce and sell his products. The influx of apprentices, as well as the collapse of the uniform price, marked the guilds' total loss of control of the trade.

\section{Transitions of designs and techniques}

The same dynamics that led to the collapse in pricing power, also impacted the visual design of Chinese carpets. In the earlier years of the industry, carpets mainly displayed traditional Chinese patterns. But following the wartime export boom, they began to cater increasingly to American middle class tastes. By the late 1920s, Tianjin carpets were so westernized in design that they were referred to in the U.S. as the "Chinese Art Deco Rug". The change of designs that made Chinese rugs increasingly popular among American buyers resulted from the establishment of a new hierarchy of knowledge in which knowledge of the consumer market was valorized, while the embodied knowledge of weavers reduced to commodified labor.

Traditional Chinese motifs that had once been prized by Western connoisseurs found themselves increasingly out of touch with the mass market. The designs of late-Qing products had been limited to a select set of conventional patterns. Weavers executed the designs by remembering the number of knots of each part of the whole composition, and adjusting proportionally to the size of the rug. When the rug contained various conventional patterns, a small illustration was attached to the side of loom as a reference. Experienced weavers were able to make the aesthetic decisions to arrange the patterns based on this reference. These earlier rugs gained popularity among the Western connoisseurs precisely because of their novelty and authenticity. However, as more of them entered Western

21. C.C. Chu and T.C. Blaisdell, Peking Rugs and Peking Boys, op. cit., p. 32. 
markets the novelty wore off and the repetitiveness of the motifs began to bore buyers.

This ambivalent attitude is shown in John K. Mumford's 1916 treatise "Chinese Rugs." Concerned about the "recent commercialization" of the Chinese rugs, he praises the coarser pieces from earlier times that "preserved to our day the ancient designs of the Chinese rug makers ${ }^{22}$." Mumford encouraged his readers to develop an appreciation for these older rugs. But even Mumford had grown weary of traditional designs. "There are designs which are to the Western eye hard and discordant ... most of these are in rugs of a religious sort, where the patterns include the dragons, Foo dogs, and other symbolic devices which seem to us grotesque and even repellent". 23

The changes in Chinese carpet design in the 1910s and 1920s closely tracked the changes in preference of the American market. Xinyu Luo, the manager of Kaiyuan Wool and Carpet Factory in Beijing acknowledged that, "In the previous years many carpets had a central medallion surrounded by floral patterns. Now we see people making carpets without medallions but more flowers". ${ }^{24}$ Not coincidentally, an article on House Beautiful in 1920 advised readers, "Avoid rugs with too arresting medallions ... If a medallion is to be used put it in the center of the room. You would not have the chandelier so placed as to disturb the structural balance of the room". ${ }^{25}$ Carpets with central medallions thus constrained the creativeness in spacial arrangement in rooms with a chandelier. This "first-world problem" was not explicitly acknowledged in any discussion of carpet making in China, but the designs of Chinese carpets evolved accordingly.

Gordon Leitch published a treatise on Chinese rugs in 1928 in which he provided a description of the change of designs of Chinese rugs. $\mathrm{He}$ divided the transformation of Chinese rugs into three stages, "the dynastic," "the transitional" and "the foreign-influenced". ${ }^{26}$ Dynastic rugs, as defined by Leitch, used a mix of Chinese traditional symbols, including royal dragons, the Buddhist lotuses and swastikas, Taoist thunder and

22. J.K. Mumford, “Chinese Rugs,"op. cit., p. 3.

23. Ibid, p. 6.

24. X. Luo, "Beijing ditan ye diaocha baogao", op. cit., p. 4.

25. H.V. Button, "The decorative use of Oriental rugs," House Beautiful, October 1920, p. 308.

26. Gordon B. Leiтch, Chinese Rugs, New York, Dodd, Mead \& company, 1928, p. 79-85. See Appendix 1 for examples of carpets designs of different periods as categorized by Leitch. 
peaches, and other auspicious symbols from popular culture such as deer and bats. But in the transitional period, Leach believed, the dramatically over use of imperial symbols mixed with designs and colors that "appealed to foreign taste" had brought some bizaar effects. ${ }^{27}$ During this period, he writes, "Returning students tried to transmit their impressions of foreign art; foreigners in China persuaded some of the Chinese to use designs and color tones which appealed to foreign taste" ${ }^{28}$ Based on interviews with former carpet dealers, Theodore Herman believed that when an exporter "supervised designs, quality, and the packing of articles," designs came from "his own head office abroad, from his customers, or from designers employed by him locally". ${ }^{29}$ When working with local designers, export companies often sent their designs to dealers in Western markets. Based on the reaction of these dealers, the exporters would then decide whether the design would be adopted. In other words, import-export companies, media publications, and individual travels were among the channels by which "Chinese-themed" designs circulated across the Pacific. The "transitional period" is therefore characterized by an increasingly diffuse, international influence on design as well as by the gradual exclusion of weavers from the design process.

The evolution in design that Leitch identified led to a concomitant revolution in the design process. From the final years of Qing to the early 1920s, carpets were increasingly made to order with specific design requests from exporters or overseas distributers. Hence, workshops started to make commensurate drafts to ensure that made-to-order designs would be faithfully executed. The person who made the commensurate drafts was referred to as a ji shi. According to Yunzhi Rui, the manager of a major carpet producer Jen-Li, a ji shi named Kuizhang Yin was the first to make a traceable draft. Rui recalls, "The customer ordered carpet(s) with dragon pattern resembling the one on the silver coin. The coin was too small to be a useful reference for the workers. Yin then made a large draft from the coin

27. Ibid, p. 84 .

28. Ibid, p. 82.

29. Theodore Herman, "An Analysis of China's Export Handicrafts Industry to 1930 ”, PhD dissertation, University of Washington, 1954, p. 182. 
pattern." Later it became common practice for workshops to make both a small colored illustration and a large draft with only the outlines. ${ }^{30}$

The draft consisted of a drawing the same size as the pattern on the final product. The draft would be inserted between the two layers of warps after the warps were tightly fixed between the loom's upper and lower beams. A worker or an apprentice would trace the pattern onto the warps. As the workers weaved, a colored illustration was hung aside as a reference. Knotters selected dyed yarns according to the colored illustration and finished the knotting in the delineated zone on the warps. As long as the weaving was thusly executed, weavers did not need to memorize the number of knots or be concerned with the proportion and balance of the design. The ji shi was thus established as a separate position. Larger workshops often employed multiple $j i$ shi who were not only in charge of producing the draft, but also involved in the training of apprentices and new workers. They were veteran workers promoted to managerial roles. Their principle duty was to ensure the design was executed as the order specified. However, as the Yin Kuizhang's case shows, the ji shi might also add his own interpretation when the request was general or vague. Though the new design process made workshops more nimble in responding to consumer demands, it also prevented workers from using their own aesthetic judgment in making the carpets. The aesthetic creativity was now the provenance of the foreign buyer and, to a lesser extent, of the $j i$ sh $i$ who translated the visual design into technical production.

The submission to foreign designs eventually allowed the Chinese carpets to blend harmoniously with the American home décor. Leith celebrated the the third stage, "the New Age in China," brought into being by "a few Western nationals who understood the Chinese better than their brothers". ${ }^{31}$ In truth, what made these "foreign-influenced" rugs successful was not actually a superior understanding of Chinese culture, but the producers' direct contact with the American retail market. Indeed, Western producers operating in China were simply following the time-tested strategy for appealing to the American consumer that they had perfected in the marketing of Western consumer goods. This strategy was identi-

30. Yunzhi RuI, "The rise and development of Tianjin carpet industry", Materials of Tianjin Culture and History, $\mathrm{n}^{\circ} 1$, December 1978, p. 64-79, p. 68.

31. G.B. Leitch, Chinese Rugs, op. cit., p. 84. 
fied in William Leach's Land of Desire. Leach describes early twentieth century American design as a process of commodification that proceeded by "appropriating folk design and image, reducing custom to mere surface and appearance". ${ }^{32}$ As consumption was, in Leach's words, "democratized," the contents of consumption goods altered. The trend of Chinese style in early twentieth-century America was thus in direct contrast with the "Chinoiserie" in the eighteenth-century Europe. The Enlightenment movement's fascination with China made the Chinese-style decoration a "critical ornament" that presented the owners in light of Chinese-like politeness and declared their embracement of the doux commerce. ${ }^{33}$ In contrast, the American consumers, especially the white, well-to-do, female homemakers, took on the oriental ornaments not to culturally align themselves with the orients, but to "affiliate with the global elite," namely the upper class of the European imperialist powers. ${ }^{34}$ For these new taste arbiters and homemakers, the "authenticity" of an Eastern rug became a problem. "Although consistent and beautiful by themselves, even with their sometimes garish colors," a writer of House Beautiful comments, "there are many [Oriental] rugs that cannot become a decorative part of the tranquil domesticity of the average home". ${ }^{35}$ The rug for the average home had foremost to showcase the owner's mastery of stylizing her own living space. In this America of democratized consumption, the theme of the Orient could still be prized, but only in so far as it submitted to the tastes and decorative principals of the American homemakers.

Harmony with American home décor was as much a chemical process as an aesthetic one, as Chinese carpet makers abandoned the use of vegetable dyes. In the past, Western connoisseurs had lauded the charm and endurance of Chinese vegetable dyes. But this charm could only be revealed through natural aging. Mumford described how the famous imperial yellow was achieved, writing, "[The worker] dyed the wool first in a fast yellow. When this was dry and thoroughly set it was dipped into a rather strong red, more or less fugitive. Upon long exposure to the air the red

32. William Leach, Land of Desire: Merchants, Power, and the Rise of a New American Culture, New York, Vintage, 1993, p. 5.

33. Stacey Sloboda, Chinoiserie: Commerce and Critical Ornament in Eighteenth-century Britain, Manchester, Manchester University Press, 2014.

34. K. Hoganson, Consumers' Imperium, op. cit., p. 253.

35. H.V. Button, "The decorative use of Oriental rugs", op. cit., p. 308. 
faded and the yellow came through; enough of the red remaining to leave the degree of warmth desired". ${ }^{36}$ The effect relied on the dyer's sense and experience, and the perfection of the color only became apparent after years of use. But middle-class carpet buyers were not attuned to the pleasures of watching a carpet age to perfection, nor indeed to the beauty of vegetable dye coloration. Chinese vegetable dyes were "brilliant" to an expert like Leitch, but "gauche" to the House Beautiful writers and the average buyers who made up its readership.

Moreover, by the late 1920s, the trend of mimicking antique rugs brought about a new finishing process called chemical wash. At the beginning, this process was done only after the carpets arrived in the United States. The vegetable coloring matters were greately affected by the process. It was almost impossible to foretell what the color would be after the chemical wash. In a short period of time, American importers all wanted carpets that used chrome dyes which proved to be much more predicatable with the chemical wash. As Chinese carpet makers adapted to the American market's preference for chrome dyed rugs, the effects were both aesthetic and economic. Chinese carpets of the 1920s would have looked completely different from vegetable-dyed carpets even a decade before, and abandoned all the regal charm that Mumford's generation of collectors had prized them for. Furthermore, chrome dyes proved more expensive than vegetable dyes, and so smaller Chinese manufactures who could not afford dyes were reduced to the status of subcontractors for larger firms. ${ }^{37}$

Thus the most successful carpets producers had to be the ones most responsive to the American market's changing preferences. This is why once the foreign direct investment entered into the carpet industry in 1923 and 1924, they immediately dominated the scene. The new players were either American citizens living in China, or branch companies headquartered in the United States. Names that were recognized later as representatives

36. J.K. Mumford, “Chinese Rugs,"op. cit., p. 6.

37. Fang Xianting and Blaisdell \& Chu all claimed that vegetable dyes and chrome dyes cost the same. But Mumford and George Richardson went into greater detail to show that at the beginning of adopting chrome dyes, the cost of carpet dyeing had increased. This increase in cost was only later offset by the increase in scale of chrome dyes caused by the demands from the American market. Richardson, then the manager of the Tianjin branch of National Aniline and Chemical Co. U.S.A, had shown that the higher expense of chrome dyeing was mainly due to investment in equipments such as steam boilers which previous vegetable dyeing did not use. George O. Richardson, “Dyeing Chinese Rugs," Textile Colorist, May 1932, p. 135-138. 
of Chinese Art Deco carpets were established during this time. In Beijing there was Helen Fette. Fette was a Wellesley graduate who came to China as a trailing spouse when her husband was hired to teach Chemistry at Qinghua University. She co-founded the Fette-Li Rug Company with Li Mengshu, a young rug workshop owner who held higher standards than his peers. ${ }^{38}$ Fette-Li's in-house designers were well-educated and highly-paid professionals of both Chinese and Western nationalities. They were known to "comb museums, libraries, and antique shops for ideas and subjects". 39

In Tianjin, Tavshanjian, Elbrook, and Nichols started carpet businesses that by the mid-1920s dominated Tianjin carpet production. Elbrook's wool mill had operated in Tianjin since at least 1920 and was a major yarn supplier for Tianjin carpet factories. In 1924 it began making its own carpets. Tavshanjian was an established carpet company in the United States owned by an Armenian family. An abundance of wool and cheap labor attracted them to Tianjin, where they opened a branch. Nichols Super Yarn, a brand name that would come to be synonymous with Tianjin rugs for dealers and collectors alike, was founded in 1924 by the American Walter Nichols. The essence of the "New Age" period of Chinese carpets was a "westernization" of design in which foreign entrepreneurs and their professional design staff systematically appropriated traditional motifs to meet the needs of the American home. This process entailed the discarding of the visual language that Chinese workshop artisans were most familiar with. As the small workshops lost the capability to develop their own products, they were compelled to rely on the subcontracts from the big factories.

\section{Standardization and quality control}

The advent of mass production and marketing brought calls for export merchants to standardize Chinese handicrafts production. The desire for standardized products in rug industry devalorized certain materials, such as hand-spun yarn and vegetable dyes, transformed the organization of production, and imposed stricter measures of quality control upon the carpet weavers. In 1927 the small workshops in Beijing and Tianjin experienced

38. Vernon Nash and Hin Wong, "New Dyes in Old China", The Rotarian, July 1931, p. 46. 39. Ibid, p. 48. 
an epidemic of "rejection" from the merchants. These spates of rejection always coincided with slack periods in the business cycle. Products whose quality would be perfectly acceptable in normal times would be suddenly turned down as a result of unfavorable business conditions. The small workshops not only earned the lowest profits, but were also forced, after the fact, to shoulder the risk of the business downturn.

It is in this context that the discussions of the "crisis" of the carpet industry flooded newspapers and journals. In the numerous charts of rising in cost and falling in sale, the analysists criticized the domination of the traders, lamented the hardship that carpet makers had to endure, and expressed their concerns with the increasingly tense relationship between capital and labor. The issue of design rarely drew any attention. When it did, the suggestions were often to study more closely the Western design patterns. ${ }^{40}$ Besides recognizing the industry's vulnerability to American market fluctuation, the writers blamed the ignorance and pettiness of the carpet makers for the crisis. Nankai University economist Fang Xianting stood as the most keen observer and acute criticizer of the carpet industry. In Fang's vision, China's modernization had to begin from the modernization of manufacturing, particularly in the light industries. ${ }^{41}$ Fang saw the small carpet manufaturers as impeding the development of the industry:

They have little capital, and even less knowledge and intelligence. Ignorant of the western markets, all their efforts can at best maintain their basic subsistence. They experienced no fun of a creator or an adventurer, possessed no vision of an industrialist. The only ways they know to gain a few tiny drops of profit are to cheat with the materials and exploit their apprentices, which only contribute in damaging their reputation and ruining their chances. ${ }^{42}$

To preempt rejection, carpet makers big and small alike began implementing their own, draconian quality controls. Quality control in the

40. The articles following the ups and downs of carpet industry were indeed numerous. The more substantial ones include "The problem of cash flow led to the rise of carpet pawning industry", The Bank Monthly, n 9, 1927, "The causes for the demise of Chinese carpet industry in recent years", Beijing Spinning, Weaving and Dyeing Institute Quarterly, $\mathrm{n}^{\circ} 1,1929$, "The carpet industry facing adversity", Economic Quarterly, n 11, 1936 and many more.

41. Margherita ZanASI, "Far from the treaty ports: Fang Xianting and the idea of rural modernity in 1930s China”, Modern China, 30, n 1, 2004, p. 113-146.

42. X. FANG, Tianjin Carpet Industry, op. cit., p. 288. 
production sites was, in its essence, not much different from the "rejection" system that exporters had imposed on small producers. For the big carpet factories in Beijing, quality control relied less on a rationalization of the carpet making process than on penalizing measures at the final inspection. Accompanied by the elaborate quality-related wage deduction system was a strict material quota system. Fette-Li's "large scale in, small scale out" measurement in effect, bought and sold from their own employees with one hand on the scale. ${ }^{43}$ The deteriorated labor-capital relationship eventually led to a whole industry strike in 1929. Beijing carpet industry never recovered from this strike and its aftermath. When the Great Depression hit the international market, many factories locked out their workers and declined to reopen after the labor protest. In the 1930s, Beijing carpet production, bearing a reputation of inferior quality and terrible labor relations, shrank to less than a quarter of its production volumes in the 1920 s.

The Great Depression devastated American demand for Chinese carpets, and even some of the most successful factories in Tianjin were caught in the downturn. Nichols went into bankruptcy in the early $1930 s .{ }^{44} \mathrm{Jen}-\mathrm{Li}$ survived to be the leading factory in Tianjin. Established by a few Americareturned Chinese industrialists, Jen-Li managed to build a much more systemized workplace, one that had abandoned the vestiges of the old, artisanal workshop production. Its factory workers enjoyed a relatively stable income, but were subject to a comprehensive set of disciplinary measures. ${ }^{45}$

\section{Conclusion}

The early Republican era was a time when China embraced industrialization with the hope of advancing its position in the global economic hierarchy. The growth of handicrafts contributed greatly to early Republican economic growth and exports, but the artisans who only produced for exports experienced deskilling and proletarianization. This paper shows that the success of Beijing and Tianjin carpets in Western markets resulted

43. J. Liv, H. Chen, and D. Zhong, "The Beijing carpet industry", op. cit., p. 59.

44. Elizabeth Bogan, "In Search of Walter Nichols," Museum Books, inc., 1996, online http:// www.cyberrug.com/bogen-walternichols.htm.

45. “Tianjin Jen-Li Industries Regulation Bylaws," Tianjin Jen-Li Industries Archive, p. 1-6. The Factory Law was promulgated in 1929 by the Nationalist government. Many of the new regulation measures in Jen-Li was the consequences of the implementation of the Factory Law. 
in a disruption of the traditional handicrafts production systems and broke down the protective function of traditional institutions such as the guild and the apprenticeship. While the "democratization" of luxury consumption in the United States gave rise to the Chinese carpet industry, the change in preferences of this market reshaped the knowledge hierarchy in carpet production. American buyers of Oriental rugs prioritized reliability and stylistic adaptability over "authenticity." Knowledge of American consumer tastes and understanding of standardized production became more important than artisanal knowledge, such as familiarity with traditional patterns and vegetable dyes. Believing that the traditional handicrafts production was backward, Chinese carpets producers forced themselves to "study and improve" in order to follow standards set by export markets. When the market desired carpets that were designed in accordance with American home décor, Chinese carpet workshops lost the initiative to design their own products. They came to rely on exporters for designs and orders. Eventually, entrepreneurs with direct connections to the foreign market came to dominate the carpet production; weavers were reduced to manual laborers.

The Great Depression hurt the industry badly, but the Sino-Japan war from 1937 to 1945 destroyed it. The last of the foreign entrepreneurs left China during the war. Carpet workers thrown out of work became rickshaw pullers, peddlers or returned to the farm. ${ }^{46}$ The industry briefly revived after the war and before the establishment of the People's Republic. After 1949, the state took over the larger factories such as Jen-Li and Fette-Li. Today, carpets are still being made in several state-owned factories, but few of them are hand woven. "Chinese rugs" have faded from the public's awareness. For those who know of them, they are simply a history now.

\section{Author}

Yujie Li is a PhD student at the University of Chicago, focusing on the history of modern China. Her research interests include history of material culture, history of technology, and history of work and life under Socialism. Contact: yjl15@uchicago.edu.

46. "The Beijing carpet industry", op. cit., p. 73-80. 